\title{
Støttetiltak for etterlatte ved selvmord
}

\author{
Ved Lars M ehlum
}

I det aller meste selumordsforebyggende arbeid har naturlig nok den selvmordsnaere stått i sentrum for innsatsen. Men i løpet av de senere år har vi fått en økende erkjennelse av hvilke problemer også de etterlatte ved selumord kan slite med, både når det gjelder problemenes omfang og art.

A lle dødsfall innebærer smertefulle tap. $M$ en det tapet som etterlatte utsettes for ved selvmord, er mer sammensatt. Det å bli aktivt forlatt av den man er glad i oppleves svært vanskelig. Etterlatte ved selvmord opplever dessuten ofte en rekke sekundære tap. Forsørgerens inntekt faller kanskje bort, og med dette blir de økonomiske vilkårene vanskelige. Kanskje må familien flytte fra sitt tilvante nærmiljø der de ellers lettere kunne fått støtte. I noen familier fører selvmordet til gjensidige anklager og konflikter, og dette kan resultere i redusert kontakt for barn og voksne med viktige familiemedlemmer. $\mathrm{H}$ os enkelte ektepar har reaksjonene og sorgprosessen etter sønnens eller datterens selvmord kjørt seg helt fast og ledet til totalt familiesammen brudd. Etterlatte familiemedlemmer kan kjenne angsten for at det skal skje et nytt selvmord i familien, at det skal hvile en slags forbannelse over familien, som en sterk tilleggsbelastning. En gjenlevende ektefelle kan føle seg overveldet av alt ansvaret som nå må bæres alene, for daglige utfordringer som man tidligere var to om, og for å ta vare på barnas sorg og reaksjoner etter tapet. Selvmord har vært tabubelagt og fortiet i mange sammenhenger. Fortsatt er det mange som gjør alt for å skjule dødsårsaken når en av de nærmeste tar sitt eget liv, og får da heller ikke del i de vanlige sorgritualene. Begravelsen foregår i all stillhet. På denne måten avskjærer de etterlatte seg fra muligheter for hjelp og støtte fra venner, naboer eller kolleger som kanskje ikke kan løse problemene, men som kan lytte og delta. Enda mer alvorlig er nok den fortielsen som kan skje internt i familier. Den fører til at det ikke blir mulig å snakke åpent om det som skjedde, og om følelsene som følger med. A It dette vi her har nevnt, øker risikoen for at etterlatte ved selvmord i sterkere grad enn andre etterlatte kan utvikle alvorlige og langvarige psykiske, familiemessige eller sosiale problemer. $\mathrm{H}$ vordan disse problemene arter seg, har vi beskrevet tidligere i Suicidologi ( $M$ ehlum 1997), og vi skal ikke gå videre inn på det i denne sammenheng. Her skal vi i stedet peke på hvilke forebyggende støttetiltak det i dag er naturlig å anbefale for enkeltpersoner, familier og andre grupper etterlatte ved selvmord. Til slutt skal vi se på noen nyere utviklingstrekk i det forebyggende arbeidet blant etterlatte.

\section{Profesjonell eller frivillig bistand?}

I de nærmeste dagene etter dødsfallet vil etterlatte ofte først og fremst ha behov for tid og rom til å gi uttrykk for sine føl elser og reaksjoner, og støtte og hjelp til å løse små og store problemer. De trenger også informasjon som kan bidra til å $ø k e$ deres evne til å forstå og akseptere sine egne og andres reaksjoner, og hva som kan gjøres for å takle alle utfordringene. D et kreves ingen spesialutdanning for à kunne imøtekomme de fleste av disse behovene. $M$ en det kreves menneskevett.

Fagfolk bør bidra til å styrke vanlige menneskers tillit til at det de kan bidra med ikke bare er et plaster på såret i mangel av profesjonell bistand, men at det de gjør er av grunnleggende betydning. På den annen side bør helsepersonell og andre profesjonelle hjel pere være årvåkne for spesielle behov eller situasjoner som fordrer aktiv innsats fra deres side. Det kan være behov for et tilbud om støtten de samtaler med målsetting å lette den naturlige og nødvendige sorgprosessen. I enkelte tilfeller kan det utvikle seg patologiske sorgreaksjoner der det handler om sorg som er mer intens og langvarig enn normalt. Det kan utvikles alvorlige depressive symptomer og i en del tilfeller endog post-traumatiske stressreaksjoner. Slike symptomer eller reaksjoner vil medføre betydelig redusert livskval itet over lengre tid, og for enkelte kan det faktisk føre til selvmord. H elsepersonell har her en viktig forebyggende innsatså gjøre ved tidlig å gripe inn med behandling og bistand.

\section{Gruppeintervensjon}

0 fte er en hel gruppe personer berørt ved et selvmord. Da tenker vi særlig på primærfamilien, men i noen tilfeller også på kollegene på arbeidsplassen eller kameratene i den nærmeste krets. Ikke sjelden kan de profittere på å få hjelp som gruppe i løpet av de første dagene etter selvmordet. En slik gruppeintervensjon, som følger prinsippene for emosjonell debrief (gruppe stress debrief) (W eisæth \& M ehlum 1993), utføres typisk 24-72 timer etter dødsfallet, og er kanskje aller mest påkrevet når det dreier seg om dramatiske omstendigheter og de etterlatte er blitt utsatt for sterke og opprivende sanseinntrykk. I dag fins det mange helsearbeidere og andre hjel pere omkring $\mathrm{i}$ kommunene som har nødvendig kompetanse i å utføre emosjonell debrief. Slik gruppeintervensjon overfor etterlatte ved selvmord er derfor realistisk gjennomførbar de fleste steder og bør vurderes $\mathrm{i}$ mange situasjoner.

\section{Hva med barna?}

Barna har dessverre ofte blitt glemt når familier rammes av dødsfall og sorg, og dette gjel der særlig når omstendighetene er så spesielle og traumatiske som de ofte er ved selvmord. M en også barn har be-

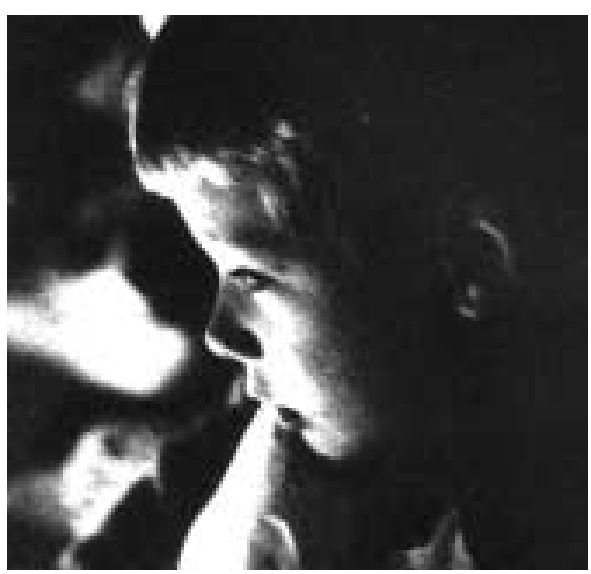

hov for å få sørge. D et er dessuten en rekke grunner til at vi nettopp bør ta med barna i sorgen og ha et våkent øye for deres behov i slike tilfeller (M ehlum 1999, M üller 1997). Vi har massiv dokumentasjon på hvordan tap av viktige personer i tidlige barneår kan føre til en sårbarhet som senere kan gi opphav til depresjon og andre psykiske problemer. Foreldre og andre etterlatte med omsorgsansvar for barn 


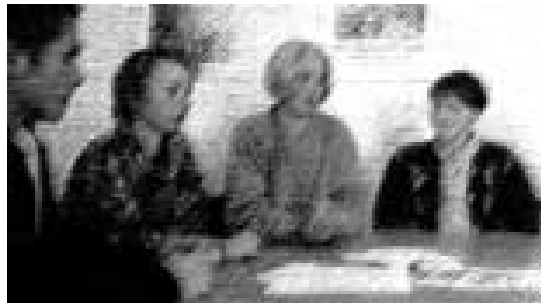

vil ofte ha nytte av tilgang på fagpersoner, men hvor mye bistand som er nødvendig i det enkelte tilfelle varierer naturlig nok sterkt, og det er viktig at familiene selv får styre dette. De fleste familier vil ha stor nytte av råd og veiledning i hvordan de skal fortelle barnet om selvmordet på en måte som barnet kan forstå, men som heller ikke tilslører de faktiske forhold ( $R$ aundalen 2000, M ehlum 1999). I visse tilfeller kan det være påkrevet med en mer aktivt intervenerende strategi fra fagfolks side når de trekkes inn i arbeidet med å følge opp barn som har opplevd selvmord i sin nærhet. Det gjelder særlig når det er en av foreldrene som har tatt sitt eget liv, eller dersom barnet har vært vitne til selvmordet eller vært den som fant avdøde.

\section{Sorggrupper}

Den prosessen som skal til for at etterlatte skal komme over sitt tap og de tilknyttede føl elsesmessige reaksjonene, kaller vi sorgarbeidet. $\mathrm{Og}$ denne prosessen tar tid mye mer tid en $n$ de første turbulente og handlingsmettede dager og uker. Sorgarbeidet er en sunn og helt nødvendig prosess. Det er nok mulig å utsette eller undertrykke sorgen en stund, men dette vil i så fall koste mye krefter som må dreneres fra mer konstruktive og byggende prosesser. A undertrykke sorgen vil for mange bety å bli sittende fast $i$ en tilstand av vedvarende sjokk og utslåtthet, mens sorgprosessen i stedet bidrar til at den sørgende klarer å omstille seg tankemessig og følel sesmessig fra det livet som var til det livet som er. $\mathrm{H}$ vilke ressurser som den enkelte vil ta i bruk i sin prosess og hvordan den enkelte sørger, kan variere sterkt, og vi skal være varsomme med å foreskrive noen standardløsninger. M ange etterlatte ved selvmord opplever det som en stor hjelp å få møte og samtale med likesinnede - mennesker som selv har mistet sine kjære under liknende omstendigheter. $\mathrm{H}$ eldigvis har vi sett at sorggrupper og selvhjelpsgrupper for etterlatte ved selvmord har vokst fram en rekke steder i $\mathrm{N}$ orge, som regel som resultat av ildsjelers innsats. (Seksjon for selvmordsforskning og -forebygging har lagt en oppdatert landsdekkende oversikt over kontaktpersoner for sorggrupper ut på sine Internettsider, http://www.med.uio.no/ipsy/ssff.)

O ppleggene og fremgangsmåtene kan variere fra sted til sted, men målsettingen for gruppene er felles: å gjenopprette tilfredsstillende livskvalitet og forebygge psykisk lidelse (og selvmordshandlinger).

\section{Får etterlatte \\ ved selvmord nok hjelp?}

Sosiologen Kari Dyregrov har nylig publisert resultater fra sin undersøkelse av det offentlige hjelpetilbudet til etterlatte ved unges selvmord, se nærmere omtale av funnene i dette nummeret av Suicidologi, s.16 ff. Tilbakemeldinger fra 321 av landets kommuner ga grunnlag for følgende konklusjoner: I de fleste kommunene kom hjel peapparatet raskt i kontakt med de etterlatte, men tidspunkt og måte kontakt ble etablert på syntes tilfel dig, oppføl gingstiden varierte og tilbudet til barna var mangelfullt. Et bedre omsorgstilbud og økt tilgjengelighet til tilbudet syntes å være mest vanlig i mindre kommuner og i kommuner med fast koordinator, kriseteam og skriftlige rutiner for omsorgen (Dyregrov et al. 1999). Dyregrov anbefaler at en handlingsplan for krise- og sorgberedskap bør utarbeides i alle kommuner.

\section{LEVE - Landsforeningen for etterlatte ved selvmord}

0 vennevnte undersøkelse bekrefter det inntrykket vi har hatt at omsorgen for etterlatte ved selvmord er mangelfullt utbygget i vårt land. Innsatsen må styrkes på flere av de områder vi har nevnt i denne artikkelen. $0 \mathrm{~g}$ i dette arbei det er de etterlatte selv en sentral ressursgruppe som kan og vil bidra. Det var derfor en milepæl da Landsforeningen for etterlatte ved selvmord - LEVE - ble stiftet i desember 1999. Foreningen har som hovedmål å bidra til å sikre at etterlatte ved selvmord får god nok støtte og oppfølging. For tiden arbeides det med oppbygging av organisasjonsapparatet og utforming av strategier og sentrale tiltak. Flere ildsjeler deltar i denne prosessen, og det ytes bistand både fra Statens helsetilsyn og SSFF. Det er grunn til å anta at denne foreningen vil få stor betydning i årene som kommer, og i dette og senere nummer av Suicidologi vil det være aktuelt stoff om virksomheten som drives i foreningens regi .

\section{Utviklingen videre}

O gså i andre land ser vi at etterlatte ved selvmord går sammen i foreninger og stiftel ser for å styrke innsatsen overfor egen gruppe. I vårt naboland Sverige har foreningen SPES (Suicid prevention och efterlevandes stöd) (spes er latin og betyr håp) allerede vært i sving noen år og har iverksatt betydelig virksomhet sentralt og regionalt. I USA har vi foreningen SPA N (Suicide preven-tion advocacy network) ( span er engelsk og betyr å bygge bro). Stifterne av denne organisasjonen har konsentrert mye av innsatsen om å påvirke politikere og andre beslutningstakere til å få etablert et nasjonalt selvmordsforebyggen de program i U SA - og de har lykkes med det. I stadig flere land ser vi at etterlatte kan spille en aktiv rolle ikke bare i å dra omsorg for seg selv og likesinnede, men også i å forebygge selvmord i en større sammenheng. Den internasjonale foreningen for selvmordsforebygging - IA SP - fokuserer også etter hvert mer på de etterlattes situ-asjon, og vi kan regne med at samarbeidet mellom fagfolk og frivillige vil bli styrket gjennom dette.

A It dette konstruktive arbeidet vi her har nevnt, har blitt mulig fordi tabuene og stigmaet ved selvmord ikke lenger er så knugende. D et gir grunn til optimisme når vi tenker på hvilket engasjement som i tiden fremover kan vekkes for selvmordsforebyggende virksomhet i brede lag av befolkningen.

\section{Litteratur}

Dyregrov K, Dyregrov A, N ordanger D. 0 msorg for etterlatte etter selvmord. Tidsskrift for Den norske lægeforening 1999; 119: 4010-5.

W eisæth L og M ehlum L (red.): M ennesker, traumer og kriser. 0 slo: U niversitetsforlaget, 1993.

M ehlum L. Etterlatte ved selvmord. $\mathrm{H}$ va er de vanlige reaksjonene, og hvordan kan vi hjelpe? N ytt i suicidologi 1997; 2 (1): 18-20.

M ehlum L: Etter selvmordet. I: M ehlum L.(red.): Tilbake til livet. Selvmordsforebygging i teori og praksis. Kristiansand: Høyskoleforlaget, 1999.

M üller, 0: B arn som etterlatte etter foreldres selvmord. N oen teoretiske og kliniske refleksjoner. Tidsskrift for N orsk Psykologforening 1997; 34: 859-67.

Raundalen $\mathrm{M}$ : $\mathbf{H}$ va skal vi si til barn om selvmord? Suicidologi 2000; 5 (2): 12-15. 